\title{
Tradition and Renewal in Contemporary Orthodox Theology
}

\author{
Marios Begzos \\ Dean of the School of Theology, University of Athens \\ mbegzos@theol.uoa.gr
}

\begin{abstract}
Marios Begzos, Tradition and Renewal in Contemporary Orthodox Theology, Elpis, 16 2014: 19-22.
Abstract: This text presents the challenges that the modern world poses for the Orthodox Church. In every historical period, the Church has struggled with internal and external problems. While preserving its traditions and historical foundations, the theology of the Orthodox Church struggles with contemporary problems by showing the current, contemporary teaching about God, man and the world.
\end{abstract}

\begin{abstract}
Streszczenie: Niniejszy tekst przedstawia zadania, jakie przed Kościołem prawosławnym stawia współczesny świat. W każdej z epok Kościół zmagał się z problemami zewnętrznymi i wewnętrznymi. Teologia prawosławna zachowując tradycję i historyczne fundamenty, zmaga się ze współczesnymi problemami ukazując aktualną, współczesną naukę o Bogu, człowieku i świecie.
\end{abstract}

Keywords: Tradition, Orthodoxy, theology, renewal, aims of theology

Słowa kluczowe: Tradycja, Prawosławie, teologia, odnowa, zadania teologii

\section{The Cultural Problem: East and West}

Orthodoxy is marked by unique historical circumstances. It comes from the East, but addresses the West. Its origins are in the eastern basin of the Mediterranean area and in the eastern hemisphere of the European continent, but it addresses the entire inhabited earth, from the African continent to the American hemisphere of our planet, and to the Asian reaches of the Near and Far East. The nucleus of Orthodox theology is to be found in the yesterday of Christianised Hellenism, but its rays encircle the tomorrow of a global civilisation. How can our theology today be interpreted culturally?

Our Church is eastern, but the contemporary world is western. The classic pairing "Church-World" has been changed to the cultural bi-polarity "East-West". In this way, however, we slip quite easily from theology to the "demonology" of civilization. If we were to identify the East with the Church and the West with the World, we would arrive at a fatal inequality: "Eastern Church - Western World", which means that the "good" is on the side of the Church and on the banks of the East, while the "bad" lies on the side of the World and in the river bed of the West. The Manichaeism of such a formulation is something that is more than obvious.

One group of our theologians magnifies the cultural difference East-West and widens the distance into a gaping chasm. Another group of our colleagues minimizes this difference to such a degree that it nullifies any existing and almost identifies two totally different understandings of European civilization. Modern Western European culture is both egocentric and Eurocentric. It believes in its supremacy over other cultures and is founded on individualism, subjectivity and egocentricity. The traditional eastern European culture of the Orthodox is "prosopocentric" (person-centered) and "personalistic". The essential difference East-West, Church-World, Eastern Church - Western World or Orthodox - Heterodox is ontological and is encapsulated in the difference between "personalism" and individualism, and in the traditional "prosopocentrism" and the modern egocentrism.

Unfortunately, however, this existing difference is clouded by false evaluations and polarizations around the cultural differentiation of Orthodoxy. Each magnification of the difference between East and West results in the isolation of our theology from Europe and from the rest of the world. Theological insulation carries with it the cultural provincialism of Orthodoxy. The unhealthy off-springs of this attitude are instances of nationalism, narrow-mindedness and phyletism (racism). But, on the other hand, each diminution of the cultural difference East-West brings with it the assimilation of Orthodox cultural precepts by the modern Western European mentality resulting finally in a cultural internationalism of Orthodoxy, however without either roots in tradition or a resistance to decay. In this way the ecumenicity of Orthodoxy is corrupted into syncretism and its catholicity is mis-shapen into a universality.

\section{The Ecclesiological Problem: Ecumenism and Orthodoxy}

Western European civilization is heterodox: either Roman Catholic or Protestant. Orthodoxy encounters heterodoxy and engages in theological dialogue with it. This constitutes the ecumenical movement of our age and poses with a sense of urgency the following ecclesiological problem: How can we as Orthodox theologians engaged in ecumenical dialogue offer our witness, confess the uniqueness of our tradition, and simultaneously assist our heterodox brethren to discover authentic Orthodoxy? 
The critical point is this: How can the ecumenicity of the Orthodoxy be revealed within the ecumenical movement? For this must occur by overcoming the barriers of diplomatic ecumenism that is reduced to ecclesiological syncretism and a confessional Orthodoxy which degenerates into a Christian sect. Here again arise monstrous polarizations between syncretism and sectarianism thereby confusing ecumenism with ecumenicity.

Orthodox theology is obliged to take into consideration a number of factors. The issue is not about the union of the churches but the unity of the Church. Orthodoxy is a way of life, a fact of life, a matter of true faith encapsulated in a proposocentric ontology that constitutes the most priceless treasure of Christianity.

Only on the basis of such a starting point can we distinguish ecumenism from ecumenicity. When we say Orthodoxy, we mean ecumenicity. This presupposes that the truth of life which is contained in Orthodox tradition has value in the entire length and breadth of the inhabited earth. A further consequence of Orthodox ecumenicity is that our tradition can' t be limited geographically (as "Eastern") nor culturally (as "Grecophone") nor racially nor nationally. An Orthodoxy that is not ecumenical becomes unorthodox. The most worthy and most meaningful epithet that applies to the Patriarchate of Constantinople is "Ecumenical" and perhaps it is not simply a historical coincidence that this title has penetrated the self-consciousness of our faithful.

Therefore the ecumenicity of Orthodoxy is necessarily and unavoidably witnessed within the ecumenical movement of our age. It is not by chance that already from the critical decade of the 1920s, the Ecumenical Patriarchate undertook a historical initiative in the ecumenical movement with its inspired encyclical. Neither is it coincidental that the Ecumenical Patriarchate strongly supported the post-war revival of the ecumenical movement with the institution of the World Council of Churches. Without the Ecumenical Patriarchate, the modern ecumenical movement would have been confined to a Protestant confederation of missionary societies and theological schools. It is the ecumenicity of Orthodoxy that gives the breath of life to the ecumenical movement, and this by virtue of the theological self-consciousness of the Ecumenical Throne of Constantinople.

Thus we Orthodox give witness of our tradition to the Christian world and we demonstrate the ecumenicity of our tradition within the ecumenism of our age. Contemporary ecumenism needs Orthodox ecumenicity to find its raison d' être. But also our ecumenicity has need of the ecumenical movement for it to find yet another means of expression.

\section{The Religious Problem: Dialogue of Religions}

If the West produces culture, the East gives birth to religions. All of the so-called "great", "universal", historical religions were born in Asia: in the Near East the monotheistic faiths (Judaism, Islam) and in the Far East the polytheistic faiths (Hinduism, Buddhism, etc.). If the confrontation of Orthodoxy with the West poses a cultural problem, which we have already touched on together with the ecclesiological question, then the encounter of Orthodoxy with the East brings to the forefront the religious problem. What relations and what differentiations exist between Orthodoxy and the East (Near and Far) with its polytheistic or monotheistic, prophetic or mystical religions?

If we over-emphasise the differences between the church and religion, we then have the "westernisation" of Orthodoxy, that is we identify the church both with the West and with Europe. This results in the sectarianisation of Christianity, which sees itself as absolute, superior and unique compared with any other eastern spirituality or Asiatic religious identity.

If, on the other hand, we minimize the difference between the church and religion, we then have the "easternisation" of Orthodoxy. This means that the church closely approaches the Eastern Asiatic that we fall into the temptation to alter Orthodox asceticism into a "Christian yoga", reducing "neptic hesychia" to a so-called "European nirvana". We re-cast the Orthodox elder into a Western "yogi", we degenerate the Holy Mountain into a Mediterranean Tibet, we forge Orthodox tradition into a "West European Buddhism". And all of this certainly leads to a syncretism of heterogeneous religious persuasion and exotic mystical attitudes. As a result of the current theological lethargy there is a pseudo religious fashion which both beguiles and is beguiled.

Orthodox theology needs especially to be on guard against this. It is not enough to define Orthodoxy with regard to the West, but it is also obligatory to delineate it from the East - avoiding syncretism and sectarianism, exaggerations and minimizations of differences, the westernisation and orientalisation of the church. It is urgent to remind ourselves that Orthodoxy is not the East, as it is usually stated simplistically. Nor indeed is it the West.

Orthodoxy is the East of the West, and the West of the East. It resides at the eastern end of the Western hemisphere and is located at the western part of the eastern world. Orthodoxy is the bridge between East and West. It is neither equal to the European West nor the Asiatic East (be in the Near or Far East). A ready example is the center of Orthodoxy: Constantinople. Let us call to mind its geographical position on the Bosphorus to understand immediately what Orthodoxy as a bridge between East and West means.

Constantinople bridges Asia with Europe and Orthodoxy bridges the East with the West. Just as the City (New Rome) unites two continents, so the Church unifies two worlds, the East and the West, the Asian mother of religions with the European father of cultures.

\section{The Technological Problem: Environment and Ecology}

Technology, especially today, cuts across religions and civilizations. On a short term basis it satisfies our daily needs, but in the long term it threatens our freedom, as we 
can see from the use of nuclear power in war or in peace, from the destruction of the natural environment and the problems of information technology. One of the main dilemmas of technology that theology faces concerns the ethics of technology and especially the choice between economy and ecology.

Technology should make a moral choice: either it will obey the demands of economy, or it will choose the priorities of ecology. If technology has as its criterion the personal profit of the capitalist investor, then it will submit to economy. If the main criterion is the social benefit of employment and the main concern the protection of environment, then technology follows the road of ecology. Thus, modern advanced technology confronts an inevitable moral dilemma: economy or ecology?

The difference between the economical and ecological choice is at the same time axiological and ontological. With economy we aim at quantitative development, in ecology we aim at qualitative development. The question is no longer so simple: yes or no to development. But it is about the most delicate and immensely critical dilemma: which development, what kind of development, quantitative or qualitative, economic or ecological?

In the first case we aim at increasing the quantity of products and services. In the second case we seek a better quality of life. In quantitative development "what" and "how much" we produce is of chief consideration. In qualitative development the question "how" and "why" we produce is of primary concern. The economy serves quantitative development and ecology serves qualitative development.

The financial-quantitative development is based on the individual and his interest, his selfishness and utilitarianism, his individualism and egocentricity. The criterion remains as the individual interest of the capitalist investor-employer.

On the other hand, ecological qualitative development is based on disinterest and altruism, and the neglect of self for the sake of other things such as the physical and social environment. That which counts is no longer the individual with his own interests but nature and work, the entire universe and man as a whole, natural and the social environment. Instead of capital serving as the unique force, the social and environmental aspects of man should be seen as the most important.

It scarcely needs to be said that behind all of these factors are hidden individualism, self-centredness, vainglory and utilitarianism. Technology is becoming the other face of morality. Orthodoxy with its theological personalism must today confront technological individualism. This is necessary in order to avoid the danger of a "neo-paganism" with a naive "return to nature".

\section{The Ideological Problem: Politics, Globalisation, Nationalism}

Morality has two faces: one is called technology, the other politics. The reality of Orthodox theology requires it to cultivate today a political morality. Otherwise we find ourselves drifting between a hypocritical non-political position, reminiscent of pharisaism, and a hyper-critical fragmented politics, reminiscent of zealotism. Apart from these two extreme positions, we need to give meaning to politics, to redirect it towards morality and to give to it ontological significance. The initial question: "What is politics?" often remains unanswered.

Politics is not the art of the attainable, as conservative circles claim, because as such immorality is justified and the cynicism in the doctrine "the purpose sanctifies the means" is endorsed. Politics is not a technique by which one seizes power, as the radicals of any epoch desire, for as such politics becomes a means of suppression and of the depersonalization of humanity.

If in the past theology had to cope with politics, today especially Orthodox theology cannot but be the pioneer in its formation. A catalyst in these developments was the shattering events of the last decades with the collapse of the regimes of so-called "existing socialism" in Eastern Europe. Specifically, the political message of these events was the following: ideology is waning.

The process of democratization in the ex-Eastern alliance is based on the demolition of every ideological scheme. It is not about a simple process from socialism to liberalism, as naive observers of politics imagine, neither is it an exchange of communism with capitalism, as selfish opportunists would wish for.

The people of Eastern Europe are thirsty for freedom, not for liberalism. The frenzied consumption that they were engaged in at the beginning of the political change was only the symptom of a "child's illness". The deprivation of freedom for centuries was expressed in the deprivation of comforts. For these reasons the people articulated their thirst for freedom as a hunger for consumption.

What they longed for was freedom, not liberalism nor consumption. What they hated was ideology, any ideology no matter what the shade. They yearned for life and fled from ideology. What they desired was a meaning for life, for wherever life begins there ideology ends. Wherever an ideology dies, life is resurrected.

With uncommon theological clarity and exemplary pastoral boldness, the Ecumenical Patriarch Bartholomew stated the following at the European Parliament in Strasbourg: "The avoidance of theology in various ideological systems was unable to convince anyone that they could provide realistic solutions. Behind the contemporary impasses of European life a theological stance is hidden" (19 April 1994).

Finally, a further aspect of the political problem in our theology is "Islamism" which is spreading from the Middle East to the Balkans and beyond the Caspian Sea. Orthodoxy has always distinguished between "Islam" and "Islamism". It respects the faith of Islam and knows how to live peacefully with its faithful. But it rejects Islamism as an ideology that exploits the faith for imperialistic purposes. Orthodoxy rejects in Islamism the fanaticism of the masses and the dark spirit of its leadership. For this reason it pleads 
for "peace and tolerance", using as its basis the "Declaration of Bosphoros" (1994). Orthodox theology must prepare properly the stewards of the Church for a peaceful co-existence and theological dialogue with Islam so that the illness of Islamism may be placed in the margins of history.

The fate of theology lies in the hands of God and in those of the theologians. If God is able to resurrect from stones the children of Abraham, He can also allow the destruction of Jerusalem, the collapse of Rome, the fall of Constantinople.

This means that we must neither rest from nor avoid our responsibilities by falsely relying solely on the love of God. God granted us freedom and responsibility and it is for this reason that He has allowed the destruction of the "holy cities" in every phase of history. It is our duty to carry out our responsibilities especially in the important area of Orthodox theology today.
What this means is that we should today take historic initiatives. It is urgent for us now to acquire a historic sensitivity. The eschatological reorientation of theology is of special importance because eschatology grants ecclesial conscience with prophetic inspiration, radical nerve, critical sharpness for the necessary "discernment of spirits" and recognizing the "signs of the times".

If there is to be any distinction among men, this will not have to do with intelligence but with sensitivity. Men of sensitivity have been responsible for the progress of history while its delay has been the fault of the insensitive. Intelligence does not guarantee progress, sensitivity does. The intelligent man is not only clever, he is also cunning. For these reasons, intelligence is necessary but not sufficient.

What we need most is a sensitivity towards history, a sense of reality and tenderness towards life. If these be the aims of Orthodox theology today, it would then have fulfilled its task fully. 